\title{
Influence of ad libitum milk replacer feeding and butyrate supplementation on the systemic and hepatic insulin-like growth factor I and its binding proteins in Holstein calves
}

\author{
D. Frieten, ${ }^{*}$ C. Gerbert,† C. Koch,† G. Dusel, ${ }^{*}$ K. Eder,‡ A. Hoeflich,§ B. Mielenz,\# and H. M. Hammon\# ${ }^{1}$ \\ *Department of Life Sciences and Engineering, University of Applied Sciences Bingen, 55411 Bingen am Rhein, Germany \\ †Educational and Research Centre for Animal Husbandry, Hofgut Neumuehle, 67728 Münchweiler an der Alsenz, Germany \\ łInstitute of Animal Nutrition and Nutrition Physiology, Justus-Liebig-University Giessen, 35392 Giessen, Germany \\ §Institute of Genome Biology, and \\ \#Institute of Nutritional Physiology “Oskar Kellner," Leibniz Institute for Farm Animal Biology (FBN), 18196 Dummerstorf, Germany
}

\begin{abstract}
Ad libitum milk feeding and butyrate (B) supplementation have the potential to stimulate postnatal growth and development in calves. The somatotropic axis is the main endocrine regulator of postnatal growth and may be affected by both ad libitum milk replacer (MR) feeding and B supplementation in calves. We hypothesized that ad libitum MR feeding and B supplementation stimulate systemic and hepatic insulin-like growth factor (IGF)-I and IGF binding proteins (IGFBP) in preweaning calves. Sixty-four (32 male, 32 female) Holstein calves were examined from birth until wk 11 of life. Calves received MR either ad libitum (Adl) or restrictively $(6 \mathrm{~L} / \mathrm{d}$; Res). In each feeding group half of the calves received a MR with $0.24 \%$ butyrate and the other half received same MR without butyrate. Ad libitum MR feeding was performed from d 4 until wk 8 of age. From wk 9 to 10, Adl and Res calves were gradually weaned and were fed $2 \mathrm{~L} / \mathrm{d}$ until the end of the trial. Concentrate, hay, and water were freely available. Feed intake was measured daily and body weight weekly. Blood samples for analyzing plasma concentrations of glucose, insulin, IGF-I, and IGFBP-2, -3, and -4 were taken on $\mathrm{d} 1,2,4$, and 7 , then weekly or every other week (IGFBP) until wk 11 of life. Liver samples were taken on $\mathrm{d} 50$ and at the end of the study (d 80) to measure gene expression of the growth hormone receptor 1A (GHR1A), IGF1, IGFBP1 to 4, and of the IGF Type 1 and insulin receptor in the liver. Intake of MR and body weight were greater, but concentrate intake was lower in Adl than in Res. Plasma concentrations of IGF-I and IGFBP-3 were greater and plasma concentration of IGFBP-2 was lower in Adl than in Res during the
\end{abstract}

Received July 31, 2017.

Accepted October 28, 2017.

${ }^{1}$ Corresponding author: hammon@fbn-dummerstorf.de ad libitum milk feeding period. After reduction of MR in both groups to $2 \mathrm{~L} / \mathrm{d}$ plasma concentrations of IGF-I and IGFBP-4 were lower and plasma concentration of IGFBP-2 was higher in Adl than in Res. Supplementation of B depressed plasma IGF-I from wk 1 to 4 and in wk 9. On d 50, mRNA abundance of the GHR1A and $I G F 1$ was greater and of $I G F B P 2$ mRNA was lower in Adl than in Res. At d 80, IGFBP2 mRNA was greater in Adl than in Res, and IGFBP2 mRNA increased with B supplementation. Ad libitum MR feeding stimulated the systemic and hepatic IGF system and mirrored the greater growth rate during the ad libitum MR feeding, whereas butyrate supplementation partly reduced the systemic and hepatic IGF system.

Key words: calves, ad libitum feeding, butyrate, somatotropic axis

\section{INTRODUCTION}

Intensive milk or milk replacer (MR) feeding programs could improve energy and nutrient intake, body growth (Hammon et al., 2002; Jasper and Weary, 2002; Bartlett et al., 2006), and organ development in calves (Geiger et al., 2016; Schäff et al., 2016; Soberon and Van Amburgh, 2017). A greater growth and development early in life could potentially affect the lifetime performance of dairy cows (Bar-Peled et al., 1997; Bach, 2012; Van Amburgh and Soberon, 2013); in addition, these feeding programs might promote robustness during the critical time period before weaning (Ollivett et al., 2012; de Passillé et al., 2016; Khan et al., 2016). Intensive or ad libitum milk feeding, starting in the colostral period, may enhance the synthesis and release of IGF-I; IGF-I belongs to the somatotropic axis and is an important factor stimulating postnatal growth (Breier et al., 2000; Khan et al., 2011; Hammon et al., 2012). The postnatal interaction of growth hormone (GH) and IGF-I, together with its binding proteins (IGFBP), affect body growth and organ development 
in mammals (Etherton and Bauman, 1998; Breier et al., 2000), including the development of the mammary gland (Akers, 2006; Weaver and Hernandez, 2016) and immune function (Clark, 1997). Because the plasma concentrations of IGF-I and IGFBP depend on nutrient intake (Thissen et al., 1994; Savage, 2013), the increased protein and energy intake from elevated milk or MR feeding might affect the blood and tissue level of IGF-I and its binding proteins (Bartlett et al., 2006; Maccari et al., 2015; Schäff et al., 2016). Therefore, changes of the components of the somatotropic axis due to an intensive MR feeding program may at least partly explain the accelerated mammary gland development in preweaning calves (Geiger et al., 2016; Soberon and Van Amburgh, 2017).

Butyrate is known as a natural growth-stimulating substrate that enhances growth performance in young mammals and has the potential to interfere with parameters of the somatotropic axis (e.g., by stimulation of GH and IGFBP release; Tsubaki et al., 2001; Guilloteau et al., 2010; Miletta et al., 2014). In preweaning calves, butyrate supplementation in MR increases BW, structural growth, and health and affects insulindependent glucose metabolism (Guilloteau et al., 2010; Górka et al., 2011; Kato et al., 2011). Recent findings in preweaning calves indicates that ad libitum MR feeding stimulates body growth and anabolic metabolism, but butyrate supplementation did not further improve postnatal growth either in ad libitum or restrictive MRfed calves (Frieten et al., 2017). The objective of the present study was to verify the previously published effects on body growth due to ad libitum MR feeding and butyrate supplementation by investigating the systemic and hepatic IGF-I system including IGFBP as main regulators of postnatal body growth in calves.

\section{MATERIALS AND METHODS}

\section{Animals, Feeding, and Diets}

The animal experiment at the Educational and Research Centre for Animal Husbandry, Hofgut Neumuehle, Germany, was recently described in a companion paper (Frieten et al., 2017). The experimental procedures were performed in accordance with the German Animal Welfare Act (Federal Republic of Germany, 2014) and were approved by the relevant Department for Animal Welfare Affairs [Landesuntersuchungsamt Rheinland-Pfalz, Koblenz, Germany (23 177-07/G 13-20-069)]. Briefly, 64 Holstein calves ( $\mathrm{n}=32$ each for male and female) were used from birth until $80 \pm 2$ (mean $\pm \mathrm{SD}$ ) days of life. After birth, the calves were brought to individual straw-bedded calf hutches. This husbandry lasted for $10 \pm 3 \mathrm{~d}$ (mean $\pm \mathrm{SD}$ ) before the calves were finally housed in an open, straw-bedded stable. In each pen, young calves were separated from the older group for 2 to $3 \mathrm{wk}$, with a self-feeding station and separate access to concentrate, hay, and water. The health of the calves was evaluated by daily rectal temperature measurement and navel and feces examination until 3 wk of age. Health maladies, such as diarrhea, pneumonia, and navel ill, were documented and treated by a veterinarian. Clinical data from this study will be presented in a companion paper.

During the first $2 \mathrm{~h}$ after birth, all calves received 2.5 $\pm 0.09 \mathrm{~kg}$ (mean $\pm \mathrm{SD}$ ) of colostrum via bottle. Subsequently, the calves were allocated to 1 of the 4 feeding groups regarding their sex, birth weight, and cow parity to create equal groups. For the following 5 meals (until d 3 of life), calves were fed acidified transition milk $(2 \mathrm{~mL}$ of acidifier/L of milk, H. W. Schaumann GmbH, Pinneberg, Germany) with teat buckets either in amounts of $3 \mathrm{~L}$ per meal (Res; $\mathrm{n}=32$ ) or ad libitum (Adl; $\mathrm{n}=32$ ). From d 4 on, all calves were fed MR (12.5\% solids, $21.9 \%$ CP, $18.6 \%$ crude fat; Trouw Nutrition Deutschland GmbH, Burgheim, Germany) either without (B-) or with $(\mathbf{B}+)$ supplementation of calcium-sodium butyrate $(0.24 \%$ as fixed to the MR powder; Benelux GmbH, Amel, Belgium) in amounts of either $6 \mathrm{~L} / \mathrm{d}$ (ResB- and ResB+; $\mathrm{n}=16$, respectively) or ad libitum (maximum $25 \mathrm{~L} / \mathrm{d}$; AdlB- and AdlB $+; \mathrm{n}=16$, respectively). The ingredients and the chemical composition of the MR were presented in the companion paper (Frieten et al., 2017) and are given in the Supplemental Table S1 (https://doi.org/10.3168/ jds.2017-13603). The dose for butyrate supplementation in MR was adapted from the work of Górka et al. (2011) and the butyrate intake in ResB- and ResB+ is presented in the Results section. The MR allowance to all calves was reduced linearly between d 57 and 70 , and thereafter calves continue to receive $2 \mathrm{~L}$ of $\mathrm{MR} / \mathrm{d}$ until the end of the trial. In the calf hutches, feeding took place twice a day at 0700 and $1700 \mathrm{~h}$. To guarantee ad libitum feed intake, buckets for Adl calves were maintained and calves had the chance to drink MR all the time. Buckets were refilled at noon, if necessary. Teat buckets were covered with a lid to ensure that no rain or dirt contaminated the milk. In the stable, feeding was conducted using automatic feeding systems for $\mathrm{MR}$ and concentrate (Förster-Technik GmbH, Engen, Germany). Milk replacer was fed in small portions, with a maximum of $2 \mathrm{~L}$ per meal for Res calves and $5 \mathrm{~L}$ per meal for Adl calves, followed by an off time of $2 \mathrm{~h}$ for Res calves and $30 \mathrm{~min}$ for Adl calves after the end of the meal. Water and hay were freely available, and concentrate as pelleted starter (Raiffeisen Waren-Zentrale 
Rhein-Main eG, Köln, Germany; Supplemental Table S1) was offered ad libitum in the stable.

\section{Measurement of Performance Data}

During the period in the calf hutches, the daily milk and MR intake was documented by weighting residues with an electronic scale (Sartorius AG, Göttingen, Germany). In the stable, data of MR and concentrate intake were sent automatically from the automatic feeding system to the connected computer program (FörsterTechnik GmbH). The nutrient compositions of MR and concentrate were analyzed by an accredited external laboratory (Landwirtschaftliche Untersuchungs- und Forschungsanstalt, Speyer, Germany) according to the Weender standard procedure (Naumann and Bassler, 2004).

The birth weight was measured on a platform scale after the first colostrum intake. The exact amount of ingested colostrum was subtracted from the initial weight. The BW in wk 7 and 11 was recorded using a mobile scale (Tru-Test Ltd., Auckland, New Zealand). The ADG was calculated from BW with the precise number of days between weekly weight measurements.

\section{Blood and Liver Sampling and Analyses}

Blood samples were taken from the jugular vein before first colostrum intake (d 1), $24 \mathrm{~h}$ after colostrum intake (d 2), before first MR intake (d 4), and then weekly from d 7 to 77 , or once every other week from d 21 for IGFBP. All calves were fasted for at least 1 $\mathrm{h}$ before blood sampling. The blood was collected in evacuated tubes (Greiner Bio-One GmbH, Frickenhausen, Germany) containing potassium-EDTA (1.8 mg/ $\mathrm{mL}$ ) to determine plasma concentrations of insulin (on d 49 and 77), IGF-I, and IGFBP-2, -3, and -4; and tubes containing sodium fluoride $(2-4 \mathrm{mg} / \mathrm{mL})$ and potassium oxalate $(1-3 \mathrm{mg} / \mathrm{mL})$ to determine plasma glucose concentration on d 49 and 77 . Blood samples were cooled in ice water until centrifugation at $3,500 \times$ $g$ for $10 \mathrm{~min}$ at room temperature. The supernatants from plasma were pipetted into aliquots and stored at $-20^{\circ} \mathrm{C}$ until analyzed.

The glucose concentration in blood plasma was analyzed spectrophotometrically (HORIBA ABX SAS, Montpellier, France) using the kit \#A11A01667 (Axon Lab AG, Baden, Switzerland). Plasma concentration of insulin (\#RIA-1257) was determined by RIA using kits from DRG Instruments GmbH (Marburg, Germany), which were adapted to bovine (Hammon et al., 2009). Intra- and interassay coefficients of variation for insulin were 3.7 and $5.5 \%$, respectively. Plasma concentra- tion of IGF-I was measured by ELISA adapted from Daxenberger et al. (1998) using an anti-human IGF-I polyclonal antiserum (GroPep, Adelaide, Australia) that showed $100 \%$ cross-reactivity to bovine IGF-I. For standard preparation, recombinant human IGF-I (receptor grade, GroPep) was used and IGFBP were blocked with excess of human IGF-II (GroPep). Biotinyl human IGF-I was obtained from Ibt GmbH (Binzwangen, Germany). Intra- and interassay coefficients of variation were 6.4 and $9.1 \%$, respectively. Recoveries of 3 IGF-I concentrations added to different samples were $93.4 \% \pm 1.7,90.8 \pm 1.8$, and $90.8 \pm 2.7 \%$. The IGFBP-2, -3 , and -4 were analyzed in plasma using quantitative Western ligand blot analysis, as previously described (Laeger et al., 2014; Schäff et al., 2016).

On d $50 \pm 2$ and $80 \pm 2$ (mean \pm SD; d 80 females only), about 80 to $100 \mathrm{mg}$ of liver tissue was collected from each calf by biopsy (modified from Swanson et al., 2000) with a Bard Magnum biopsy instrument and Bard Magnum core tissue biopsy needle (C.R. Bard Inc., Covington, GA). The sample notch of a 12 -gauge biopsy needle contained about 20 to $30 \mathrm{mg}$ of liver tissue. To collect several biopsies while avoiding additional stress and abdominal pain for the calves, we used a Bard TruGuide coaxial biopsy needle that remained in the abdomen for the duration of biopsy. Liver samples of male calves on $\mathrm{d} 80 \pm 2$ (mean \pm SD) were collected after calves were harvested at the end of the study. Liver samples were flushed in ice-cold $0.9 \% \mathrm{NaCl}$ and frozen in liquid nitrogen. For further analysis, the liver tissue was pulverized in liquid nitrogen. The relative mRNA abundance of genes related to the IGF system was quantified as previously described (Saremi et al., 2012; Schäff et al., 2016). Primer sequences and PCR conditions for reference genes [hippocalcin-like 1 (HPCAL1), low-density lipoprotein 10 (LRP10), and RNA polymerase II (POLR2A)] and target genes [growth hormone receptor 1A (GHR1A), IGF-I (IGF1), IGFBP-1 (IGFBP1), -2 (IGFBP2), -3 (IGFBP 3$)$, and -4 (IGFBP4), IGF Type 1 receptor $(I G F 1 R)$, and insulin receptor $(I N S R)]$ were recently published (Kendall et al., 2003; Saremi et al., 2012; Schäff et al., 2016). The primer products were verified by sequencing applied with the BigDye Terminator v1.1 Cycle Sequencing kit and an ABI 3130 Genetic Analyzer (Thermo Fisher Scientific Inc., Waltham, MA). Real-time PCR was performed with the use of a LightCycler (F. Hoffman-La Roche AG, Basel, Switzerland); SYBR Green I (F. Hoffman-La Roche AG) was used as the fluorescent dye. Melting curve analysis and agarose gel electrophoresis were used to confirm the specificity of the PCR products. Quantification cycle values and amplification efficiencies obtained with the 
use of LinRegPCR version 2013.0 (Ruijter et al., 2013) were imported into qBASE+ version 2.6.1 (Biogazelle, Zwijnaarde, Belgium) for all subsequent calculations and quality controls (Schäff et al., 2016). The geometric mean of the reference gene abundances was applied for normalization. The data are presented as the ratio of the copy number of the respective gene of interest to the geometric mean of the reference gene abundance.

\section{Statistical Analyses}

Data were evaluated by repeated-measures ANOVA using PROC MIXED in SAS for Windows (release 9.4; SAS Institute Inc., Cary, NC). The ANOVA model contained the fixed effects of feeding regimen (milk; Res vs. Adl), butyrate supplementation, time (wk 1-7 and 8-11 for performance data; d 49 and 77 for BW and for plasma glucose and insulin; d 50 and 80 for tissue data; time of frequent blood samples for plasma IGF-I and IGFBP), sex, and respective interactions. Repeated measures on each calf were considered using the repeated statement of the MIXED procedure with an unstructured type of the block diagonal residual covariance matrix structure (plasma IGF-I and IGFBP) or with an autoregressive residual covariance structure (performance data, plasma glucose and insulin, gene expression data; SAS Institute Inc.). Least squares means and their standard errors were computed for each fixed effect, and all pair-wise differences of least squares means were tested with the Tukey-Kramer procedure. The SLICE statement of the MIXED procedure was used to conduct partitioned analyses of the least squares means for interactions. Differences in data with $P$-values $<0.05$ were defined as significant, and $P$-values $<0.1$ were considered as trends. Values are presented as least squares means \pm standard error if not declared otherwise in the text.

\section{RESULTS}

\section{Feed Intake and Growth Performance}

Data for feed intake and growth performance are presented in Table 1 and focused on the time periods of wk 1 to 7 (before MR reduction) and 8 to 11 (MR reduction), respectively. In both time periods, milk intake was greater in Adl than in Res calves $(P<0.001)$. On the contrary, concentrate intake in wk 8 to 11 was greater in Res than in Adl calves $(P<0.001)$. Total DMI in wk 1 to 7 was greater $(P<0.001)$ in Adl than in Res calves. The DMI was not affected by butyrate supplementation and by sex. In B-supplemented groups, B intake was greater $(P<0.001)$ in AdlB+ than in ResB+. Butyrate intake was $3.3 \pm 0.1 \mathrm{~g} / \mathrm{d}$ for wk 1 to 7 and $2.6 \pm 0.09 \mathrm{~g} / \mathrm{d}$ for wk 8 to 11 in $\mathrm{AdlB}+$, and was $1.7 \pm 0.1 \mathrm{~g} / \mathrm{d}$ for wk 1 to 7 and $1.1 \pm 0.09 \mathrm{~g} / \mathrm{d}$ for wk 8 to 11 in ResB + . The BW was greater $(P<$ $0.001)$ at the end of wk 7 (d 49) and at the end of wk 11 (d 77) in Adl than in Res (Table 1). The ADG was higher from wk 1 to $7(P<0.001)$ but lower from wk 8 to 11 in Adl than Res groups $(P<0.001)$. Body weight $(P<0.06)$ and ADG $(P=0.1)$ at wk 11 tended to be higher in $\mathrm{B}$ - than $\mathrm{B}+$ calves (Table 1 ).

\section{Plasma Concentrations of Glucose, Insulin, IGF-I, and IGF Binding Proteins}

The results of glucose and insulin concentrations in blood plasma are presented in detail in the companion paper (Frieten et al., 2017). Plasma glucose and insulin concentrations decreased in Adl calves but increased in Res calves from d 49 to $77(P<0.001$; Table 2$)$. Plasma glucose concentration was higher on d $49(P<0.001)$ in Adl than in Res calves, but was lower on d $77(P<$ 0.05) in Adl calves than in ResB-. Plasma insulin concentration was much higher in Adl than in Res calves at d $49(P<0.001)$, but did not differ between Adl and Res calves on $\mathrm{d} 77$ of age.

The plasma concentration of IGF-I slightly increased $(P<0.05)$ from d 1 to 2 and decreased $(P<0.001)$ from d 4 to 14 of age in all groups. Plasma IGF-I increased $(P<0.001)$ in Adl groups from wk 3 on, but in Res calves increased from wk 7 on $(P<0.001$; Figure $1 \mathrm{~A})$. We noted a distinct decrease of plasma IGF-I in Adl calves from wk 9 to $10(P<0.001)$. Plasma IGF-I was higher from wk 1 to $9(P<0.01)$, but was lower $(P$ $=0.02)$ at wk 11 in Adl than in Res calves. Butyrate feeding depressed plasma IGF-I from wk 1 to 4 and at wk $9(P<0.05)$. Plasma IGFBP-2 concentration decreased $(P<0.001)$ during first week of age and then increased $(P<0.01)$ until wk 2 in all groups (Figure 1B). Thereafter, plasma IGFBP-2 remained high in Res calves, but decreased $(P<0.1)$ and remained low until wk 9 in Adl calves. Plasma IGFBP-2 concentration significantly differed from wk 3 until the end of the trial, with higher concentrations in Res calves up to wk 9. At wk 11, plasma IGFBP-2 decreased $(P<0.1)$ in Res calves and increased $(P<0.001)$ in Adl calves, indicating higher concentrations in Adl than Res calves at wk $11(P<0.01)$. Plasma IGFBP-3 concentration decreased $(P<0.001)$ during first week of age in all groups, and was greater $(P<0.01)$ in Adl than in Res calves from wk 3 to 9 (Figure 1C). We observed a trend for a greater IGFBP-3 plasma concentration at wk 11 in Adl than Res calves $(P=0.07)$. Calves fed butyrate had a lower IGFBP-3 plasma concentration on d 1 and 
Table 1. Dry matter intake of liquid and concentrate feed, BW, and ADG of calves fed milk and milk replacer (MR) either ad libitum or restrictively and supplemented MR without (ResB-; AdlB-) or with $0.24 \%$ butyrate (ResB+; AdlB+) ${ }^{1}$

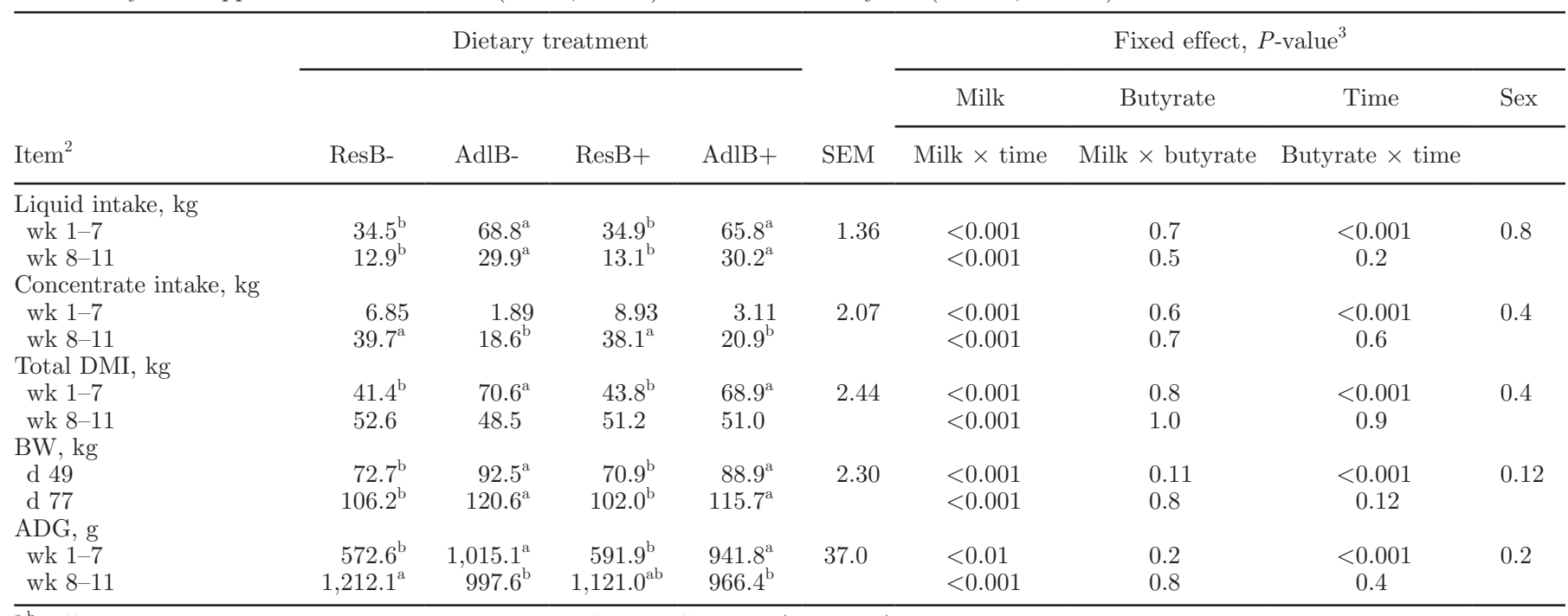

${ }^{\mathrm{a}, \mathrm{b}}$ Different letters within the same row indicate significant differences $(P \leq 0.05)$.

${ }^{1}$ Modified from Frieten et al., 2017.

${ }^{2}$ Values are presented as LSM.

${ }^{3}$ Main fixed effects are presented in 2 rows: first row indicates $P$-value for milk (ad libitum versus restrictive), butyrate supplementation, time, and sex; second row indicates $P$-values for interaction milk $\times$ time, milk $\times$ butyrate, and butyrate $\times$ time

7 of age $(P \leq 0.05)$. Plasma IGFBP-4 concentration increased $(P<0.001)$ after birth, but decreased $(P<$ 0.001 ) from $\mathrm{d} 4$ to 21 in all groups (Figure 1D) and was greater $(P<0.05)$ in Res than in Adl calves on $\mathrm{d} 1,63$, and 77 of age.

\section{Hepatic Gene Expression Related to the IGF System}

The hepatic gene expression of GHR1A, IGF1, $I G F B P 1,-2,-3$, and $-4, I G F 1 R$, and INSR are presented in Table 3. The mRNA abundance of GHR1A and $I G F 1$ on d 50 was greater $(P<0.02)$ in Adl than in Res calves, with highest abundance for IGF1 in AdlB-, but did not differ on $\mathrm{d} 80$. The abundance of IGF1 mRNA was greater $(P=0.03)$ in male than in female calves. Male calves had a greater $(P<0.001) I G F B P 1$ mRNA abundance and tended to have a greater $(P=$ 0.07) IGFBP3 mRNA abundance than female calves. The mRNA encoding for IGFBP2 changed with time $(P=0.02)$, and was greater $(P<0.001)$ on $\mathrm{d} 50$ but was lower $(P=0.01)$ on d 80 in Res than in Adl calves. On d 50, IGFBP2 mRNA was greatest $(P<0.05)$ in

Table 2. Blood plasma concentrations of glucose and insulin in calves fed milk and milk replacer (MR) either ad libitum or restrictively and supplemented MR without (ResB-; AdlB-) or with $0.24 \%$ butyrate (ResB+; AdlB+) ${ }^{1}$

\begin{tabular}{|c|c|c|c|c|c|c|c|c|c|}
\hline Item $^{2}$ & \multicolumn{4}{|c|}{ Dietary treatment } & & \multicolumn{4}{|c|}{ Fixed effect, $P$-value ${ }^{3}$} \\
\hline $\begin{array}{l}\text { Glucose, } \mathrm{mmol} / \mathrm{L} \\
\text { d } 49 \\
\text { d } 77\end{array}$ & $\begin{array}{l}5.07^{\mathrm{b}} \\
5.66^{\mathrm{a}}\end{array}$ & $\begin{array}{l}5.79^{\mathrm{a}} \\
4.84^{\mathrm{b}}\end{array}$ & $\begin{array}{l}4.99^{\mathrm{b}} \\
5.39^{\mathrm{ab}}\end{array}$ & $\begin{array}{l}6.13^{\mathrm{a}} \\
4.97^{\mathrm{b}}\end{array}$ & $\begin{array}{l}0.18 \\
0.18\end{array}$ & $\begin{array}{c}0.3 \\
<0.001\end{array}$ & $\begin{array}{l}0.8 \\
0.14\end{array}$ & $\begin{array}{l}0.01 \\
0.3\end{array}$ & 0.7 \\
\hline
\end{tabular}

${ }^{\mathrm{a}, \mathrm{b}}$ Different letters within the same row indicate significant differences $(P \leq 0.05)$.

${ }^{1}$ Modified from Frieten et al., 2017.

${ }^{2}$ Values are presented as LSM.

${ }^{3}$ Main fixed effects are presented in 2 rows: first row indicates $P$-value for milk (ad libitum versus restrictive), butyrate supplementation, time, and sex; second row indicates $P$-values for interaction milk $\times$ time, milk $\times$ butyrate, and butyrate $\times$ time. 

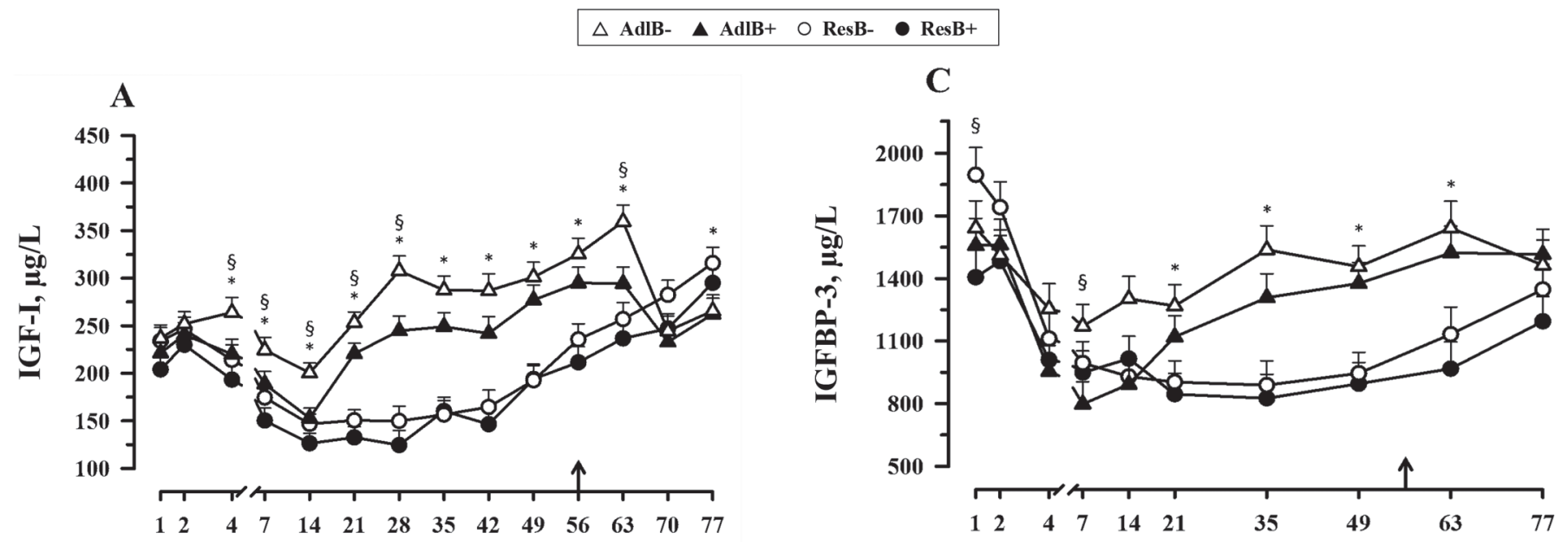

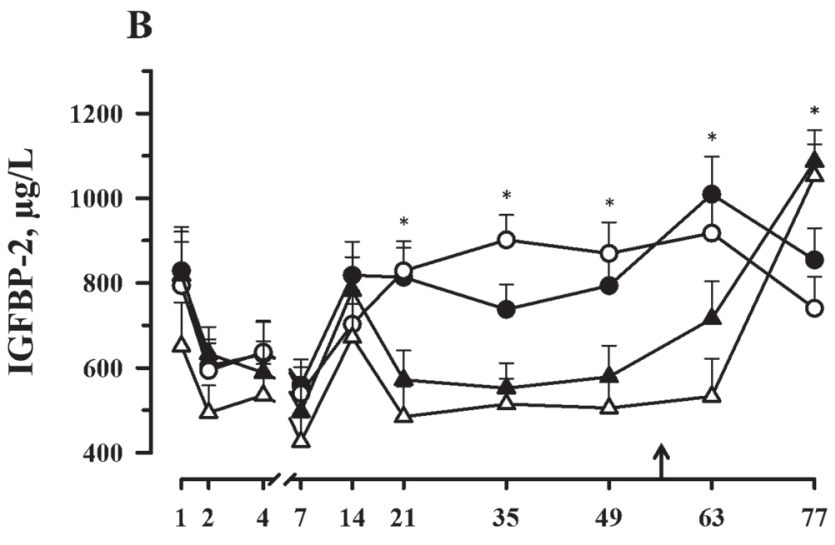

Time after birth, $d$

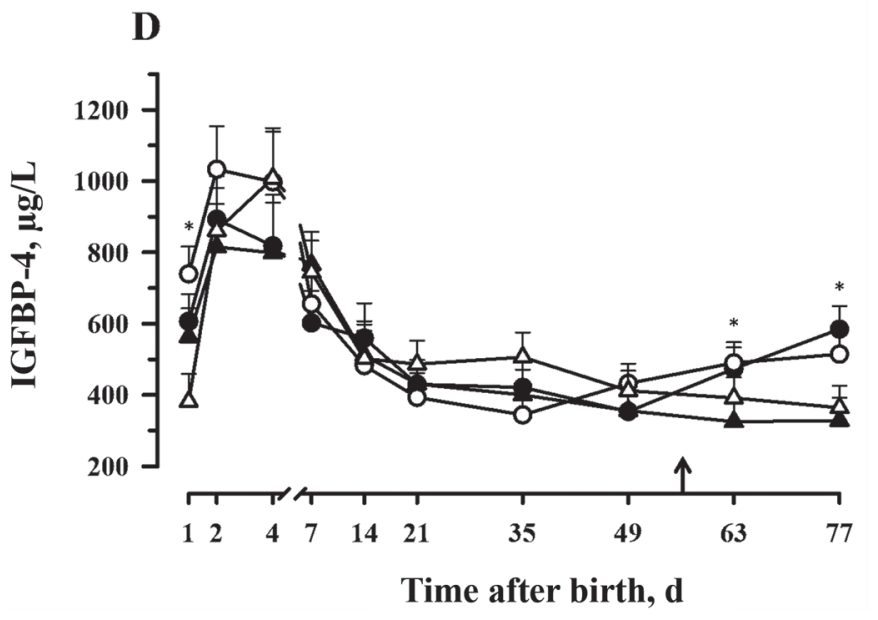

Figure 1. Blood plasma concentrations of IGF-I (A), IGF binding protein (IGFBP)-2 (B), IGFBP-3 (C), and IGFBP-4 (D) in calves fed milk and milk replacer (MR) either ad libitum or restrictively and supplemented MR without $(\triangle$, AdlB-; $\bigcirc$, ResB-) or with $0.24 \%$ butyrate $(\boldsymbol{\Lambda}$, $\mathrm{AdlB}+; \bullet$, ResB +$)$. Arrows mark the start of weaning. Data are presented as LSM \pm SEM; an asterisk $(*)$ indicates effect of feeding regimen $(P<0.05)$; a section mark $(\S)$ indicates effect of butyrate supplementation $(P<0.05)$.

ResB + and on d 80 butyrate supplementation affected $I G F B P 2$ mRNA, with greatest expression in AdlB + . The abundance of IGFBP $4 \mathrm{mRNA}$ increased with time $(P<0.01)$ in all feeding groups. The mRNA abundance of $I G F 1 R$ tended $(P=0.07)$ to be greater in Res than in Adl calves on d 50, and the mRNA abundance of INSR showed a tendency $(P=0.06)$ for the butyrate $\times$ time interaction with an increasing abundance from d 50 to 80 in butyrate-fed calves.

\section{DISCUSSION}

Calves with unlimited milk and MR intake for $8 \mathrm{wk}$ postnatal more or less doubled their MR intake compared with Res calves fed $6 \mathrm{~L}$ of MR/d. Such a great liquid feed intake was previously reported in other studies with dairy calves that were allowed to drink milk or MR ad libitum for a distinct time period after calving (Hepola et al., 2008; Maccari et al., 2015; Korst et al., 2017). On the other hand, concentrate intake was lower in Adl than in Res calves and the increase in concentrate intake was delayed in Adl calves (Frieten et al., 2017). An impaired concentrate intake in calves due to unrestricted milk feeding (Jasper and Weary, 2002) or enhanced MR feeding (Kristensen et al., 2007; Davis Rincker et al., 2011) was previously observed in some, but not in all studies (Maccari et al., 2015; Schäff et al., 2016; Korst et al., 2017). In addition, calves receiving elevated amounts of milk, but no ad libitum milk feeding, during the first weeks of life had a greater concentrate intake after the intensive milk feeding period and after weaning (Khan et al., 2007). Therefore, the management of the intensive milk feeding period might have an important effect on the concentrate intake in 
Table 3. Relative mRNA expression $\left(\log _{2}\right)$ of liver samples in calves fed milk and milk replacer (MR) either ad libitum or restrictively and supplemented MR without (ResB-; AdlB-) or with $0.24 \%$ butyrate (ResB+; AdlB+)

\begin{tabular}{|c|c|c|c|c|c|c|c|c|c|}
\hline \multirow{2}{*}{$\begin{array}{l}\text { Relative mRNA } \\
\text { expression related } \\
\text { to reference genes }\end{array}$} & \multicolumn{4}{|c|}{ Dietary treatment } & \multirow{2}{*}{ SEM } & \multicolumn{4}{|c|}{ Fixed effect, $P$-value ${ }^{3}$} \\
\hline & ResB- & AdlB- & ResB+ & AdlB + & & $\frac{\text { Milk }}{\text { Milk } \times \text { time }}$ & $\frac{\text { Butyrate }}{\text { Milk } \times \text { butyrate }}$ & $\frac{\text { Time }}{\text { Butyrate } \times \text { time }}$ & Sex \\
\hline \multicolumn{10}{|l|}{ GHR1A } \\
\hline d 50 & 0.55 & 0.69 & 0.57 & 0.73 & 0.06 & 0.03 & 0.4 & 0.9 & \multirow{2}{*}{0.3} \\
\hline d 80 & 0.59 & 0.63 & 0.63 & 0.68 & 0.06 & 0.2 & 0.9 & 0.8 & \\
\hline \multicolumn{10}{|l|}{$I G F 1$} \\
\hline d 80 & 24.6 & 18.3 & 20.5 & 21.6 & 2.20 & $<0.01$ & 0.7 & 0.7 & 0.03 \\
\hline \multicolumn{10}{|l|}{$I G F B P 1$} \\
\hline d 50 & 228 & 239 & 342 & 372 & 157 & 0.3 & 0.2 & 0.2 & \multirow[t]{2}{*}{$<0.001$} \\
\hline d 80 & 361 & 389 & 331 & 655 & 125 & 0.5 & 0.4 & 1.0 & \\
\hline \multicolumn{10}{|l|}{$I G F B P 2$} \\
\hline d 50 & $7.07^{\mathrm{ab}}$ & $4.25^{\mathrm{b}}$ & $7.86^{\mathrm{a}}$ & $4.21^{\mathrm{b}}$ & 0.90 & 0.7 & 0.09 & 0.02 & \multirow[t]{2}{*}{0.7} \\
\hline d 80 & $4.98^{\mathrm{b}}$ & $7.02^{\mathrm{ab}}$ & $6.78^{\mathrm{ab}}$ & $9.92^{\mathrm{a}}$ & 1.00 & $<0.001$ & 0.9 & 0.07 & \\
\hline \multicolumn{10}{|l|}{$I_{G F B P}$} \\
\hline d 50 & 2.71 & 2.81 & 2.69 & 2.71 & 0.22 & 0.5 & 0.9 & $<0.01$ & \multirow[t]{2}{*}{0.6} \\
\hline \multirow{2}{*}{\multicolumn{10}{|c|}{ IGF1R }} \\
\hline & & & & & & & & & \\
\hline d 50 & 2.74 & 2.69 & 4.09 & 2.54 & 0.43 & 0.2 & 0.2 & 0.5 & \multirow[t]{2}{*}{0.6} \\
\hline d 80 & 3.08 & 2.98 & 3.43 & 3.17 & 0.42 & 0.2 & 0.2 & 0.5 & \\
\hline \multicolumn{10}{|l|}{$I N S R$} \\
\hline d 50 & 6.43 & 6.53 & 5.56 & 5.50 & 0.61 & 0.7 & 0.5 & 0.3 & \multirow[t]{2}{*}{0.9} \\
\hline d 80 & 6.50 & 5.91 & 6.62 & 6.41 & 0.58 & 0.5 & 0.9 & 0.06 & \\
\hline
\end{tabular}

${ }^{\mathrm{a}, \mathrm{b}}$ Different letters within the same row indicate significant differences $(P \leq 0.05)$.

${ }^{1}$ Values are presented as LSM.

${ }^{2} G H R 1 A=$ growth hormone receptor $1 \mathrm{~A} ; I G F B P 1-4=$ IGF binding protein-1 to $-4 ;$ IGFR $1=$ IGF-I receptor; INSR $=$ insulin receptor.

${ }^{3}$ Main fixed effects are presented in 2 rows: first row indicates $P$-value for milk (ad libitum versus restrictive), butyrate supplementation, time, and sex; second row indicates $P$-values for interaction milk $\times$ time, milk $\times$ butyrate, and butyrate $\times$ time.

preruminant calves. In any case, ad libitum milk feeding (Maccari et al., 2015; Schäff et al., 2016; Korst et al., 2017) or enhanced milk feeding programs using MR with a greater CP content (Diaz et al., 2001; Bartlett et al., 2006; Khan et al., 2011) resulted in an elevated body growth during the preweaning period in calves. On the other hand, the supplementation of butyrate with the MR did not affect MR or concentrate intake in a consistent manner (Frieten et al., 2017).

The enhanced growth in Adl calves during the ad libitum milk feeding period coincided with elevated plasma concentrations of insulin, IGF-I, and IGFBP-3 and reduced plasma concentrations of IGFBP-2 during this time period. The stimulation of the postnatal somatotropic axis depends on the nutrient supply, starting in the neonatal period (Breier et al., 2000; Hammon et al., 2012; Savage, 2013), and reflects the glucose and insulin status of the animal (Breier et al., 1988; Thissen et al., 1994; Brameld et al., 1999). The nutrient intake was much greater in Adl than in Res calves during the ad libitum milk feeding period. Elevated nutrient intake affects the plasma IGF-I concentration in mam- malian (Thissen et al., 1994; Savage, 2013), including the preweaning calf (Smith et al., 2002; Daniels et al., 2008) and ad libitum milk feeding (Maccari et al., 2015; Schäff et al., 2016). The stimulating effect of elevated nutrient supply by milk or MR intake on the IGF-I plasma concentration starts postpartum (Hammon and Blum, 1997; Hammon et al., 2000; Sauter et al., 2003) and is related to the greater nutrient availability due to milk feeding (Breier et al., 1988).

The stimulation of the somatotropic axis due to ad libitum milk feeding in the present study was supported by the elevated hepatic gene expression of the liverspecific GHR1A and IGF1. Both were higher expressed in liver of Adl than Res calves at d 50 of age. The IGF-I originating from the liver contributes in a significant manner to the IGF-I in the blood plasma (Le Roith et al., 2001; Savage, 2013), hepatic IGF1 gene expression correlated with IGF-I in blood plasma of calves (Cordano et al., 2000), and its gene expression depends on the GH action in the liver (Le Roith et al., 2001; Renaville et al., 2002; Savage, 2013). The elevated glucose and insulin status at the time of ad libitum milk 
feeding may have stimulated GHR1A gene expression in the liver of Adl calves, as insulin treatment promotes hepatic GHR1A mRNA abundance in dairy cows (Butler et al., 2003; Weber et al., 2017).

The reduced insulin and IGF-I concentrations in blood plasma after the MR reduction period reflected the lower concentrate intake in Adl calves (Frieten et al., 2017). The gene expression of IGF1 as well as GHR1A in liver was not affected by the nutrient intake on $\mathrm{d} 80$ of age in a significant manner. The increase in hepatic IGF1 mRNA from d 50 to 80 in Res, but not in Adl calves, indicated that Res calves gained on nutrient intake with time due to elevated concentrate intake; Adl calves reached an elevated IGF1 gene expression level on d 50 of age and did not further increase IGF1 mRNA abundance in liver on d 80 of age. The differences in concentrate intake at the end of the study between groups (Frieten et al., 2017) were, however, not large enough to cause changes in hepatic GHR1A and IGF1 mRNA abundances between groups, but the greater concentrate intake in Res calves at the end of the study resulted in a greater plasma IGF-I concentration. Therefore, tissues other than liver that synthesize IGF-I (e.g., muscle tissue) may contribute to the elevated plasma IGF-I concentrations in Res calves on d 80 of age (Le Roith et al., 2001).

The IGFBP-3, which is part of the $150-\mathrm{kDa}$ complex and binds most of the IGF-I in blood plasma (Jones and Clemmons, 1995; Murphy, 1998), did not show an association between hepatic gene expression and plasma concentration at d 50 and 80 of age. In general, IGFBP are important regulators of the IGF-I action, and inhibitory and stimulating effects of IGFBP have been reported (Jones and Clemmons, 1995; Le Roith et al., 2001; Savage, 2013). After a decrease during the first week of postnatal life, the plasma IGFBP-3 concentration increased with age during the MR feeding period (Skaar et al., 1994; Hammon et al., 2003; Schäff et al., 2016). The increase of plasma IGFBP-3 was more dominant in Adl than in Res calves, and the dynamics of plasma IGFBP-3 concentration were similar to those of plasma IGF-I during the ad libitum milk feeding period. Although plasma GH was not measured in our study, it is well known that the IGFBP-3 status depends on GH action (Jones and Clemmons, 1995; Murphy, 1998; Savage, 2013). Obviously, GH does not directly stimulate IGFBP3 gene expression, because $I G F B P 3$ gene expression is located in nonparenchymal hepatic cells, but not in hepatocytes, and these cells do not express GH receptors (Murphy, 1998; Le Roith et al., 2001). However, both GH and IGFBP-3 are stimulated by enhanced nutrient intake in calves and growing ruminants (Renaville et al., 2002; Daniels et al., 2008). The fact that IGFBP3 gene expression in liver did not correspond to IGFBP-3 plasma concentration is probably due to IGFBP-3 synthesis in other tissues than the liver (e.g., fibroblast, endothelial cells, bone; Jones and Clemmons, 1995), and possibly due to the low number of cells in the liver (nonparenchymal cells) with IGFBP3 gene expression (Murphy, 1998; Le Roith et al., 2001). In addition, the IGFBP-3 plasma concentration depends on the proteolytic cleavage activity in the blood plasma and is probably less regulated at the transcriptional level (Jones and Clemmons, 1995). Overall, the greater plasma IGFBP-3 concentration in Adl calves corresponded to the elevated IGF-I concentration in these calves and mirrored their greater nutrient intake, but was not related to the hepatic IGFBP3 gene expression.

The IGFBP-2 status in the calves indicated corresponding changes of plasma concentration and hepatic gene expression with respect to nutrient intake. The concentration of IGFBP-2 in blood plasma and liver was lower in the Adl than in the Res calves during the ad libitum milk feeding period, but increased to a higher level in Adl calves at the end of the study when concentrate intake was greater in Res than Adl calves. The plasma IGFBP-2 concentration indicated an inverse relationship with respect to the insulin and IGF-I status in calves (Hammon and Blum, 1997; Hammon et al., 2000; Daniels et al., 2008) and dairy cows (McGuire et al., 1995), and IGFBP-2 is elevated during the catabolic state (Thissen et al., 1994; Breier et al., 2000; Renaville et al., 2002). Therefore, elevated plasma IGFBP-2 concentration may reflect the inadequate nutrient supply in Res calves during the ad libitum MR feeding period and the impaired nutrient status in Adl calves after the MR step-down period, which corresponds to findings in humans (Savage, 2013). Surprisingly, hepatic $I G F B P 1$ gene expression did not behave in the same way as hepatic IGFBP2 gene expression, but elevated IGFBP-1 status during impaired nutrient supply was shown in human patients (Thissen et al., 1994; Savage, 2013) and in neonatal calves (Sauter et al., 2003).

Plasma concentration of IGFBP-4 increased from d 1 to 2 of life, as recently reported in calves (Schäff et al., 2016), but decreased thereafter and remained more or less constant in all calves until d 63 of age, indicating no effect of ad libitum MR feeding on plasma IGFBP-4; this was in contrast to previous findings (Schäff et al., 2016), but in agreement with findings of Daniels et al. (2008) in calves. In addition, ad libitum MR feeding did not affect hepatic IGFBP 4 gene expression, but $I G F B P$ 4 gene expression increased from d 50 to 80 of age in all calves. A corresponding increase of plasma IGFBP-4 during the last weeks of the study was only seen in Res calves. The IGFBP-4 is one of the smaller 
IGFBP, with a significant plasma concentration that is decreased by IGF-I and inhibits IGF-I action (Clemmons, 1997; Duan, 2002; Firth and Baxter, 2002). Therefore, the simultaneous increase of IGFBP-4 and IGF-I in blood plasma at the end of the study in Res calves may indicate a modulation of the IGF-I activity by IGFBP-4. In addition, the MR feeding levels did not affect hepatic gene expression of IGF1R and INSR in the current trial.

Ad libitum MR-fed calves supplemented with butyrate partly indicated a lower plasma IGF-I concentration. The body growth was not stimulated by butyrate, in contrast to the finding of Górka et al. (2011), who reported greater BW in calves fed MR supplemented with butyrate. A recent review of studies with butyrate treatment in preweaning calves indicated inconsistent effects on body growth when butyrate was supplied by MR (Niwińska et al., 2017). Reasons for these different findings are not obvious, but the age of the calf when starting the butyrate supplementation could be of importance (Niwińska et al., 2017). Hepatic gene expression of GHR1A and IGF1 did not respond to butyrate supplementation in a consistent manner, but $I G F B P 2$ gene expression was elevated and INSR gene expression increased considerably in butyrate-treated groups at the end of the study. These changes on the parameters of the somatotropic axis due to butyrate supplementation may suggest that nutrient supply in butyrate-treated calves was impaired (Thissen et al., 1994; Breier et al., 2000; Renaville et al., 2002). Reasons for these findings are rather speculative; because butyrate treatment did not result in elevated plasma butyrate concentration in these calves (Frieten et al., 2017), a direct effect of butyrate on the GH-IGF-axis is not likely, as described in previous studies (Tsubaki et al., 2001; Miletta et al., 2014). Studies in calves and heifers could not find a stimulating effect of butyrate on plasma GH and IGF-I concentrations (Nosbush et al., 1996; Kato et al., 2011). In agreement with the findings on the somatotropic axis, the results on growth performance in the current study do not support data from literature that propose an improved growth rate in calves after butyrate feeding (Guilloteau et al., 2010), but do support previous findings on the lack of a growth promoting effect due to butyrate feeding in calves (Kato et al., 2011). However, intestinal mucosa growth was stimulated by butyrate supplementation in the male calves of the current study (Gerbert et al., 2017). Interestingly, this local growth-promoting effect in the small intestine did not cause an enhanced body growth in the calves of the present study.

We found no sex effects on DMI in these calves, and sex effects on growth performance were of minor im- portance. The lack of sex effects on plasma IGF-I concentration fits into this context. The lack of sex effects on growth performance and plasma IGF-I was recently described in another study of our laboratory (Schäff et al., 2016), but disagrees with earlier findings of sex effects on growth and plasma IGF-I in calves (Kerr et al., 1991; Kertz et al., 1997; Egli and Blum, 1998). However, main sex effects on growth and plasma IGF-I as well as plasma IGFBP-3 may occur when calves are older than 12 wk (Govoni et al., 2003). In this context, it was surprising to find a greater hepatic gene expression of IGF1, IGFBP1, and IGFBP3 in male than female calves, which corresponds to the overall picture of a greater somatotropic activity in males than in females (Gatford et al., 1998). Female gonadal steroids, such as estrogen, inhibit gene expression of IGF1 and $I G F B P$ in liver (Leung et al., 2004) and may explain the lower hepatic gene expression of $I G F 1$ and $I G F B P 1$ and $I G F B P 3$ in female calves; however, the interaction of gonadal sex steroids and the somatotropic axis might become more clear in older calves.

\section{CONCLUSIONS}

Feeding milk and MR ad libitum for the first $8 \mathrm{wk}$ of life affected IGF-I and IGFBP plasma concentration and hepatic gene expression. These changes mirrored the greater growth rate in Adl calves during MR feeding. At the end of the study, the greater IGF-I and lower IGFBP-2 in blood plasma in Res calves corresponded with the greater ADG in these calves. Butyrate supplementation did not stimulate growth performance but partly depressed the IGF-I status in the calves. As a consequence, the combination of an ad libitum milkfeeding program and allocation of butyrate with the MR did not result in an additional stimulation of IGF-I and IGFBP in calves.

\section{ACKNOWLEDGMENTS}

We gratefully thank Claudia Reiko [Leibniz Institute for Farm Animal Biology (FBN), Dummerstorf, Germany] and Christine and Patrick Höflich (Ligandis Gbr, Gülzow, Germany). For practical help throughout the study, we also thank the staff of the Educational and Research Centre for Animal Husbandry, Hofgut Neumuehle, and the team of Animal Nutrition and students at the University of Applied Sciences Bingen.

\section{REFERENCES}

Akers, R. M. 2006. Major advances associated with hormone and growth factor regulation of mammary growth and lactation in 
dairy cows. J. Dairy Sci. 89:1222-1234. https://doi.org/10.3168/ jds.S0022-0302(06)72191-9.

Bach, A. 2012. Ruminant Nutrition Symposium: Optimizing performance of the offspring: Nourishing and managing the dam and postnatal calf for optimal lactation, reproduction, and immunity. J. Anim. Sci. 90:1835-1845. https://doi.org/10.2527/jas.2011 -4516 .

Bar-Peled, U., B. Robinzon, E. Maltz, H. Tagari, Y. Folman, I. Bruckental, H. Voet, H. Gacitua, and A. R. Lehrer. 1997. Increased weight gain and effects on production parameters of Holstein heifer calves that were allowed to suckle from birth to six weeks of age. J. Dairy Sci. 80:2523-2528. https://doi.org/10.3168/jds.S0022 -0302(97)76205-2.

Bartlett, K. S., F. K. McKeith, M. J. VandeHaar, G. E. Dahl, and J. K. Drackley. 2006. Growth and body composition of dairy calves fed milk replacers containing different amounts of protein at two feeding rates. J. Anim. Sci. 84:1454-1467. https://doi.org/10 $.2527 / 2006.8461454 x$

Brameld, J. M., R. S. Gilmour, and P. J. Buttery. 1999. Glucose and amino acids interact with hormones to control expression of insulin-like growth factor-I and growth hormone receptor mRNA in cultured pig hepatocytes. J. Nutr. 129:1298-1306.

Breier, B. H., P. D. Gluckman, and J. J. Bass. 1988. Plasma concentrations of insulin-like growth factor-I and insulin in the infant calf: ontogeny and influence of altered nutrition. J. Endocrinol. 119:43-50.

Breier, B. H., M. H. Oliver, and B. W. Gallaher. 2000. Regulation of growth and metabolism during postnatal development. Pages 187204 in Ruminant Physiology: Digestion, Metabolism, Growth and Reproduction. P. B. Cronjé, ed. CABI Publishing, New York, NY.

Butler, S. T., A. L. Marr, S. H. Pelton, R. P. Radcliff, M. C. Lucy, and W. R. Butler. 2003. Insulin restores GH responsiveness during lactation-induced negative energy balance in dairy cattle: effects on expression of IGF-I and GH receptor 1A. J. Endocrinol. 176:205-217.

Clark, R. 1997. The somatogenic hormones and insulin-like growth factor-1: Stimulators of lymphopoiesis and immune function. Endocr. Rev. 18:157-179. https://doi.org/10.1210/edrv.18.2.0296.

Clemmons, D. R. 1997. Insulin-like growth factor binding proteins and their role in controlling IGF actions. Cytokine Growth Factor Rev. 8:45-62. https://doi.org/10.1016/S1359-6101(96)00053-6.

Cordano, P., H. M. Hammon, C. Morel, A. Zurbriggen, and J. W. Blum. 2000. mRNA of insulin-like growth factor (IGF) quantification and presence of IGF binding proteins, and receptors for growth hormone, IGF-I and insulin, determined by reverse transcribed polymerase chain reaction, in the liver of growing and mature male cattle. Domest. Anim. Endocrinol. 19:191-208. https:// doi.org/10.1016/S0739-7240(00)00073-4.

Daniels, K. M., S. R. Hill, K. F. Knowlton, R. E. James, M. L. McGilliard, and R. M. Akers. 2008. Effects of milk replacer composition on selected blood metabolites and hormones in preweaned Holstein heifers. J. Dairy Sci. 91:2628-2640. https://doi.org/10.3168/ jds.2007-0859.

Davis Rincker, L. E., M. J. VandeHaar, C. A. Wolf, J. S. Liesman, L. T. Chapin, and M. S. Weber Nielsen. 2011. Effect of intensified feeding of heifer calves on growth, pubertal age, calving age, milk yield, and economics. J. Dairy Sci. 94:3554-3567. https://doi.org/ 10.3168/jds.2010-3923.

Daxenberger, A., B. H. Breier, and H. Sauerwein. 1998. Increased milk levels of insulin-like growth factor 1 (IGF-1) for the identification of bovine somatotropin (bST) treated cows. Analyst 123:24292435. https://doi.org/10.1039/a804923h.

de Passillé, A. M., M. Rabeyrin, and J. Rushen. 2016. Associations between milk intake and activity in the first days of a calf's life and later growth and health. Appl. Anim. Behav. Sci. 175:2-7. https:// doi.org/10.1016/j.applanim.2014.10.002.

Diaz, M. C., M. E. Van Amburgh, J. M. Smith, J. M. Kelsey, and E. L. Hutten. 2001. Composition of growth of Holstein calves fed milk replacer from birth to 105-kilogram body weight. J. Dairy Sci. 84:830-842.
Duan, C. 2002. Specifying the cellular responses to IGF signals: roles of IGF-binding proteins. J. Endocrinol. 175:41-54. https://doi .org/10.1677/joe.0.1750001.

Egli, C. P. and J. W. Blum. 1998. Clinical, haematological, metabolic and endocrine traits during the first three months of life of suckling simmentaler calves held in a cow-calf operation. Zentralbl. Veterinarmed. A 45:99-118. https://doi.org/10.1111/j.1439-0442 .1998.tb00806.x.

Etherton, T. D., and D. E. Bauman. 1998. Biology of somatotropin in growth and lactation of domestic animals. Physiol. Rev. 78:745761.

Federal Republic of Germany. 2014. Tierschutzgesetz. Accessed Dec. 4, 2017. http://www.gesetze-im-internet.de/tierschg/ BJNR012770972.html.

Firth, S. M., and R. C. Baxter. 2002. Cellular actions of the insulin-like growth factor binding proteins. Endocr. Rev. 23:824-854. https://doi.org/10.1210/er.2001-0033.

Frieten, D., C. Gerbert, C. Koch, G. Dusel, K. Eder, E. Kanitz, J. M. Weitzel, and H. M. Hammon. 2017. Ad libitum milk replacer feeding, but not butyrate supplementation, affects growth performance as well as metabolic and endocrine traits in Holstein calves. J. Dairy Sci. 100:6648-6661. https://doi.org/10.3168/jds.2017-12722.

Gatford, K. L., A. R. Egan, I. J. Clarke, and P. C. Owens. 1998. Sexual dimorphism of the somatotrophic axis. J. Endocrinol. 157:373-389. https://doi.org/10.1677/joe.0.1570373.

Geiger, A. J., C. L. M. Parsons, R. E. James, and R. M. Akers. 2016. Growth, intake, and health of Holstein heifer calves fed an enhanced preweaning diet with or without postweaning exogenous estrogen. J. Dairy Sci. 99:3995-4004. https://doi.org/10.3168/jds $.2015-10405$

Gerbert, C., D. Frieten, C. Koch, G. Dusel, K. Eder, R. Zitnan, and H. M. Hammon. 2017. Impact of ad libitum milk feeding and butyrate supplementation on organ and epithelial growth in the gastrointestinal tract of dairy calves. J. Dairy Sci. 100(Suppl 2):92. (Abstr.).

Górka, P., Z. M. Kowalski, P. Pietrzak, A. Kotunia, W. Jagusiak, J. J. Holst, P. Guilloteau, and R. Zabielski. 2011. Effect of method of delivery of sodium butyrate on rumen development in newborn calves. J. Dairy Sci. 94:5578-5588. https://doi.org/10.3168/jds .2011-4166.

Govoni, K. E., T. A. Hoagland, and S. A. Zinn. 2003. The ontogeny of the somatotropic axis in male and female Hereford calves from birth to one year of age. J. Anim. Sci. 81:2811-2817. https://doi .org $/ 10.2527 / 2003.81112811 x$.

Guilloteau, P., L. Martin, V. Eeckhaut, R. Ducatelle, R. Zabielski, and F. van Immerseel. 2010. From the gut to the peripheral tissues: The multiple effects of butyrate. Nutr. Res. Rev. 23:366-384. https://doi.org/10.1017/S0954422410000247.

Hammon, H., and J. W. Blum. 1997. The somatotropic axis in neonatal calves can be modulated by nutrition, growth hormone, and Long-R3-IGF-I. Am. J. Physiol. 273:E130-E138.

Hammon, H. M., G. Schiessler, A. Nussbaum, and J. W. Blum. 2002. Feed intake patterns, growth performance, and metabolic and endocrine traits in calves fed unlimited amounts of colostrum and milk by automate, starting in the neonatal period. J. Dairy Sci. 85:3352-3362. https://doi.org/10.3168/jds.S0022-0302(02)74423 -8 .

Hammon, H. M., J. Steinhoff-Wagner, U. Schonhusen, C. C. Metges, and J. W. Blum. 2012. Energy metabolism in the newborn farm animal with emphasis on the calf: endocrine changes and responses to milk-born and systemic hormones. Domest. Anim. Endocrinol. 43:171-185. https://doi.org/10.1016/j.domaniend.2012.02.005.

Hammon, H. M., G. Stürmer, F. Schneider, A. Tuchscherer, H. Blum, T. Engelhard, A. Genzel, R. Staufenbiel, and W. Kanitz. 2009. Performance and metabolic and endocrine changes with emphasis on glucose metabolism in high-yielding dairy cows with high and low fat content in liver after calving. J. Dairy Sci. 92:1554-1566. https://doi.org/10.3168/jds.2008-1634.

Hammon, H. M., I. A. Zanker, and J. W. Blum. 2000. Delayed colostrum feeding affects IGF-I and insulin plasma concentrations in 
neonatal calves. J. Dairy Sci. 83:85-92. https://doi.org/10.3168/ jds.S0022-0302(00)74859-4.

Hammon, H. M., Y. Zbinden, H. Sauerwein, B. H. Breier, J. W. Blum, and S. S. Donkin. 2003. The response of the hepatic insulin-like growth factor system to growth hormone and dexamethasone in calves. J. Endocrinol. 179:427-435. https://doi.org/10.1677/joe.0 .1790427 .

Hepola, H. P., L. Hänninen, S. Raussi, P. Pursiainen, A.-M. Aarnikoi$\mathrm{vu}$, and H. Saloniemi. 2008. Effects of providing water from a bucket or a nipple on the performance and behavior of calves fed ad libitum volumes of acidified milk replacer. J. Dairy Sci. 91:1486-1496.

Jasper, J., and D. M. Weary. 2002. Effects of ad libitum milk intake on dairy calves. J. Dairy Sci. 85:3054-3058. https://doi.org/10.3168/ jds.S0022-0302(02)74391-9.

Jones, J. I., and D. R. Clemmons. 1995. Insulin-like growth factors and their binding proteins: biological actions. Endocr. Rev. 16:3-34. https://doi.org/10.1210/edrv-16-1-3.

Kato, S., K. Sato, H. Chida, S. G. Roh, S. Ohwada, S. Sato, P. Guilloteau, and K. Katoh. 2011. Effects of Na-butyrate supplementation in milk formula on plasma concentrations of GH and insulin, and on rumen papilla development in calves. J. Endocrinol. 211:241248. https://doi.org/10.1530/JOE-11-0299.

Kendall, P. E., T. L. Auchtung, K. S. Swanson, R. P. Radcliff, M. C. Lucy, J. K. Drackley, and G. E. Dahl. 2003. Effect of photoperiod on hepatic growth hormone receptor 1A expression in steer calves. J. Anim. Sci. 81:1440-1446. https://doi.org/10.2527/2003 $.8161440 \mathrm{x}$

Kerr, D. E., B. Laarveld, M. I. Fehr, and J. G. Manns. 1991. Profiles of serum IGF-I concentrations in calves from birth to eighteen months of age and in cows throughout the lactation cycle. Can. J. Anim. Sci. 71:695-705. https://doi.org/10.4141/cjas91-085.

Kertz, A. F., L. F. Reutzel, B. A. Barton, and R. L. Ely. 1997. Body weight, body condition score, and wither height of prepartum Holstein cows and birth weight and sex of calves by parity: a database and summary. J. Dairy Sci. 80:525-529. https://doi.org/10.3168/ jds.S0022-0302(97)75966-6.

Khan, M. A., A. Bach, D. M. Weary, and M. A. G. von Keyserlingk. 2016. Invited review: Transitioning from milk to solid feed in dairy heifers. J. Dairy Sci. 99:885-902. https://doi.org/10.3168/jds.2015 $-9975$.

Khan, M. A., H. J. Lee, W. S. Lee, H. S. Kim, S. B. Kim, K. S. Ki, J. K. Ha, H. G. Lee, and Y. J. Choi. 2007. Pre- and postweaning performance of Holstein female calves fed milk through step-down and conventional methods. J. Dairy Sci. 90:876-885. https://doi .org/10.3168/jds.S0022-0302(07)71571-0.

Khan, M. A., D. M. Weary, and M. A. G. von Keyserlingk. 2011. Invited review: Effects of milk ration on solid feed intake, weaning, and performance in dairy heifers. J. Dairy Sci. 94:1071-1081. https://doi.org/10.3168/jds.2010-3733.

Korst, M., C. Koch, J. Kesser, U. Müller, F.-J. Romberg, J. Rehage, K. Eder, and H. Sauerwein. 2017. Different milk feeding intensities during the first 4 weeks of rearing in dairy calves: Part 1: Effects on performance and production from birth over the first lactation. J. Dairy Sci. 100:3096-3108. https://doi.org/10.3168/ jds.2016-11594.

Kristensen, N. B., J. Sehested, S. K. Jensen, and M. Vestergaard. 2007. Effect of milk allowance on concentrate intake, ruminal environment, and ruminal development in milk-fed Holstein calves. J. Dairy Sci. 90:4346-4355.

Laeger, T., E. Wirthgen, M. Piechotta, F. Metzger, C. C. Metges, B. Kuhla, and A. Hoeflich. 2014. Effects of parturition and feed restriction on concentrations and distribution of the insulin-like growth factor-binding proteins in plasma and cerebrospinal fluid of dairy cows. J. Dairy Sci. 97:2876-2885. https://doi.org/10.3168/ jds.2013-7671.

Le Roith, D., C. Bondy, S. Yakar, J.-L. Liu, and A. Butler. 2001. The somatomedin hypothesis: 2001. Endocr. Rev. 22:53-74. https://doi .org/10.1210/edrv.22.1.0419.
Leung, K.-C., G. Johannsson, G. M. Leong, and K. K. Ho. 2004. Estrogen regulation of growth hormone action. Endocr. Rev. 25:693721. https://doi.org/10.1210/er.2003-0035.

Maccari, P., S. Wiedemann, H.-J. Kunz, M. Piechotta, P. Sanftleben, and M. Kaske. 2015. Effects of two different rearing protocols for Holstein bull calves in the first 3 weeks of life on health status, metabolism and subsequent performance. J. Anim. Physiol. Anim. Nutr. (Berl.) 99:737-746. https://doi.org/10.1111/jpn.12241.

McGuire, M. A., D. A. Dwyer, R. J. Harrell, and D. E. Bauman. 1995. Insulin regulates circulating insulin-like growth factors and some of their binding proteins in lactating cows. Am. J. Physiol. 269:E723-E730.

Miletta, M. C., V. Petkovic, A. Eblé, R. A. Ammann, C. E. Flück, and P.-E. Mullis. 2014. Butyrate increases intracellular calcium levels and enhances growth hormone release from rat anterior pituitary cells via the G-protein-coupled receptors GPR41 and 43. PLoS One 9:e107388 https://doi.org/10.1371/journal.pone.0107388.

Murphy, L. J. 1998. Insulin-like growth factor-binding proteins: functional diversity or redundancy? J. Mol. Endocrinol. 21:97-107.

Naumann, C., and R. Bassler. 2004. Die Chemische Untersuchung von Futtermittel. VDLUFA-Verlag, Darmstadt, Germany.

Niwińska, B., E. Hanczakowska, M. B. Arciszewski, and R. Klebaniuk. 2017. Review: Exogenous butyrate: implications for the functional development of ruminal epithelium and calf performance. Animal 11:1522-1530.

Nosbush, B. B., J. G. Linn, W. A. Eisenbeisz, J. E. Wheaton, and M. E. White. 1996. Effect of concentrate source and amount in diets on plasma hormone concentrations of prepubertal heifers. J. Dairy Sci. 79:1400-1409. https://doi.org/10.3168/jds.S0022 -0302(96)76498-6.

Ollivett, T. L., D. V. Nydam, T. C. Linden, D. D. Bowman, and M. E. Van Amburgh. 2012. Effect of nutritional plane on health and performance in dairy calves after experimental infection with Cryptosporidium parvum. J. Am. Vet. Med. Assoc. 241:1514-1520. https://doi.org/10.2460/javma.241.11.1514.

Renaville, R., M. Hammadi, and D. Portetelle. 2002. Role of the somatotropic axis in the mammalian metabolism. Domest. Anim. Endocrinol. 23:351-360. https://doi.org/10.1016/S0739 $-7240(02) 00170-4$

Ruijter, J. M., M. W. Pfaffl, S. Zhao, A. N. Spiess, G. Boggy, J. Blom, R. G. Rutledge, D. Sisti, A. Lievens, K. De Preter, S. Derveaux, J. Hellemans, and J. Vandesompele. 2013. Evaluation of qPCR curve analysis methods for reliable biomarker discovery: bias, resolution, precision, and implications. Methods 59:32-46. https://doi.org/10 .1016/j.ymeth.2012.08.011.

Saremi, B., H. Sauerwein, S. Dänicke, and M. Mielenz. 2012. Technical note: Identification of reference genes for gene expression studies in different bovine tissues focusing on different fat depots. J. Dairy Sci. 95:3131-3138. https://doi.org/10.3168/jds.2011-4803.

Sauter, S. N., E. Ontsouka, B. Roffler, Y. Zbinden, C. Philipona, M. Pfaffl, B. H. Breier, J. W. Blum, and H. M. Hammon. 2003. Effects of dexamethasone and colostrum intake on the somatotropic axis in neonatal calves. Am. J. Physiol. Endocrinol. Metab. 285:E252E261. https://doi.org/10.1152/ajpendo.00557.2002.

Savage, M. O. 2013. Insulin-like growth factors, nutrition and growth. World Rev. Nutr. Diet. 106:52-59. https://doi.org/10.1159/ 000342577.

Schäff, C. T., J. Gruse, J. Maciej, M. Mielenz, E. Wirthgen, A. Hoeflich, M. Schmicke, R. Pfuhl, P. Jawor, T. Stefaniak, and H. M. Hammon. 2016. Effects of feeding milk replacer ad libitum or in restricted amounts for the first five weeks of life on the growth, metabolic adaptation, and immune status of newborn calves. PLoS One 11:e0168974. https://doi.org/10.1371/journal.pone.0168974.

Skaar, T. C., C. R. Baumrucker, D. R. Deaver, and J. W. Blum. 1994. Diet effects and ontogeny of alterations of circulating insulin-like growth factor binding proteins in newborn dairy calves. J. Anim. Sci. 72:421-427.

Smith, J. M., M. E. Van Amburgh, M. C. Díaz, M. C. Lucy, and D. E. Bauman. 2002. Effect of nutrient intake on the development of 
the somatotropic axis and its responsiveness to GH in Holstein bull calves. J. Anim. Sci. 80:1528-1537. https://doi.org/10.2527/ $2002.8061528 x$.

Soberon, F., and M. E. Van Amburgh. 2017. Effects of preweaning nutrient intake in the developing mammary parenchymal tissue. J. Dairy Sci. 100:4996-5004. https://doi.org/10.3168/jds.2016-11826.

Swanson, K. S., N. R. Merchen, J. W. Erdman Jr., J. K. Drackley, F. Orias, G. N. Douglas, and J. C. Huhn. 2000. Technical note: a technique for multiple liver biopsies in neonatal calves. J. Anim. Sci. 78:2459-2463.

Thissen, J. P., J. M. Ketelslegers, and L. E. Underwood. 1994. Nutritional regulation of the insulin-like growth factors. Endocr. Rev. 15:80-101. https://doi.org/10.1210/edrv-15-1-80.

Tsubaki, J., W. K. Choi, A. R. Ingermann, S. M. Twigg, H. S. Kim, R. G. Rosenfeld, and Y. Oh. 2001. Effects of sodium butyrate on expression of members of the IGF-binding protein superfamily in human mammary epithelial cells. J. Endocrinol. 169:97-110. https://doi.org/10.1677/joe.0.1690097.

Van Amburgh, M. E., and F. Soberon. 2013. The role of calf nutrition and management on lifetime productivity of dairy cattle. Pages 178-197 in Cow Longevity Conference, Hamra Farm, Tumba, Sweden.

Weaver, S. R., and L. L. Hernandez. 2016. Autocrine-paracrine regulation of the mammary gland. J. Dairy Sci. 99:842-853. https://doi .org/10.3168/jds.2015-9828.

Weber, C., C. T. Schäff, U. Kautzsch, S. Börner, S. Erdmann, R. M. Bruckmaier, M. Röntgen, B. Kuhla, and H. M. Hammon. 2017. Variable liver fat concentration as a proxy for body fat mobilization postpartum has minor effects on insulin-induced changes in hepatic gene expression related to energy metabolism in dairy cows. J. Dairy Sci. 100:1507-1520. https://doi.org/10.3168/jds .2016-11808. 